\title{
Nutrient storage in roots and rhizomes of hexaploid Caucasian clover
}

\author{
D.E. STRACHAN ${ }^{1 *}$, A.H. NORDMEYER ${ }^{2}$ and J.G.H. WHITE' \\ 'Plant Science Department, PO Box 84, Lincoln University \\ ${ }^{2} N Z$ Forest Research Institute, PO Box 465, Rangiora \\ 'Present address: Ravensdown Fertiliser Co-op Ltd. PO Box 934, Blenheim
}

\begin{abstract}
Hexaploid Trifolium ambiguum M. Bieb. (Caucasian clover cv. Prairie) persisted and dominated in high country plots which received more than $100 \mathrm{~kg} \mathrm{P} / \mathrm{ha}$ at establishment. After 13 years the biomass of coarse roots (rhizomes and tap-roots) amounted to 20 tha. The contents of nutrients in the root fractions were approximately five times that in the herbage. This ability to retain nutrients in coarse roots may be a strategy that contributes to the dominance of Caucasian clover on this acid soil.
\end{abstract}

Keywords: nutrients, phosphorus, roots, Trifolium ambiguum

\section{Introduction}

Trifolium ambiguum M. Bieb. (Caucasian clover) is a perennial legume that has evolved in cold winter environments in the Caucasus region of Central Asia (Bryant 1974) and has proven to be well adapted to the high country of Australia (Yates 1993) and New -Zealand-(Daly-\&-Mason-1987)- It $^{-}$is $^{-} \mathbf{a}^{-}$persistent ${ }^{-}$and relatively drought-tolerant clover with much higher root biomass than Trifolium repens (white clover) in 2-year-old swards (Spencer et al. 1975).

This study was initiated to measure the combined rhizome and root biomass and nutrient content in hexaploid Caucasian clover which had been established for 12 and 13 years in a phosphate-gradient experiment on a high country soil in New Zealand (Davis 1991).

\section{$M$ ethods}

Site

The experiment is located at an elevation of $600 \mathrm{~m}$ at Hakatere in the Ashburton River catchment. Annual precipitation is about $800 \mathrm{~mm}$ but summer droughts and dry winds are common on the flat exposed site. The soil is a Pukaki sandy loam (dystrochrept).

\section{Treatments}

The full trial design is described by Davis (1991). In August 1979 hexaploid Caucasian clover cv. Prairie was drilled into 'native' grassland at a sowing rate of $13 \mathrm{~kg} / \mathrm{ha}$. Plots of $4 \mathrm{~m}$ (long) x $2.3 \mathrm{~m}$ (wide) were pegged and treated with variable rates of superphosphate to impose gradients of phosphorus of, 6.25, $12.5,25,50,100,200,400$ and $800 \mathrm{~kg} \mathrm{P} / \mathrm{ha}$ along each of 4 replicate blocks. Basal $\mathrm{K}, \mathrm{Mg}, \mathrm{Ca}, \mathrm{S}$, and Mo were applied to all plots (Davis 1991). The trial was not grazed or re-fertilised after establishment, and by year 12 Caucasian clover established and maintained dominance on all plots with more than $100 \mathrm{~kg} \mathrm{P} / \mathrm{ha}$ of applied fertiliser.

\section{Biomass}

Two biomass samplings were initiated, one in November-December 1991 while Caucasian clover was in vigorous early-season growth, and the other in late February 1993 when the clover was being subjected to a typical summer dry period.

The first sampling examined ecosystem components in 2 replicates of plots receiving 100, 200, 400, and $800 \mathrm{~kg} \mathrm{P} / \mathrm{ha}$ where the Caucasian clover was dominant. Quadrats of $0.1 \mathrm{~m}^{2}$ were laid down in the centre of each plot and all material was cut with a sharp knife and spade to a depth of $40 \mathrm{~cm}$ to estimate root $1 \overline{\mathbf{n}} * \overline{0}-1 \overline{0}, \quad \overline{10}-20,20-30$ and $30-40 \mathrm{~cm}$ horizons.

All material in the quadrat blocks was sorted into herbage, litter, coarse roots (rhizomes +tap roots) and fine roots (cl $\mathrm{mm}$ diameter). The dense root/soil mass was cut and washed through a series of sieves down to $0.6 \mathrm{~mm}$ mesh over large troughs. Most roots were recovered in this process. All the remaining material was then dried before re-wetting to float off any fine root fragments that had passed through a $0.6 \mathrm{~mm}$ sieve. Herbage, litter, coarse robts and fine roots were analysed for nutrients.

Root cores were not washed. Each $10 \mathrm{~cm}$ section was partially dried, crushed and sieved. very fine roots that passed through a $0.6 \mathrm{~mm}$ sieve were picked out with forceps, and all roots were amalgamated to estimate total biomass in each soil horizon. These samples were not analysed for nutrients.

At the time of sampling in February 1993 the soils were dry and hard and the herbage was desiccated. Root blocks were cut with a very sharp spade from 2 turfs in each of 4 replicates of plots that had received phosphate fertiliser at 6.25, 50, 200, and 
$800 \mathrm{~kg} \mathrm{P} / \mathrm{ha}$. The root blocks were $20 \mathrm{~cm} \times 20 \mathrm{~cm}$ in surface area and $20 \mathrm{~cm}$ deep. The blocks were then dissected and sieved to extract the coarse root (rhizome and tap root) components.. These roots were washed thoroughly, dried at $75^{\circ} \mathrm{C}$, 'and later analysed for nutrients.

\section{Nutrient analyses}

After oven-drying, components were milled and analysed,. Materials from the first collection-in year 12, were analysed for nitrogen, phosphorus, potassium, magnesium and calcium following digestion in $\mathrm{H}_{2} \mathrm{O}_{2}$ / $\mathbf{H}_{2} \mathbf{S O}_{4}$ by the methods of Nicholson (1984). Coarse roots from the year 13 excavations were analysed for nitrogen, phosphorus and sulphur by. Southern Chemical Consultants using $x$-ray fluorescence.

\section{Results}

At the time of first sampling in early summer of year 12, the Caucasian clover was making vigorous vegetative growth with no flowering. Herbage yields ranged from 2-6 t/ha with mean values of $4.2 \mathrm{t} / \mathrm{ha}$ (Table 1). Most of the litter was that- produced in the previous season and amounted to 5.8 tha. Coarse roots of 19.5 tha were the main living component of the ecosystem and coarse root:shoot ratio averaged 4.6:1. The tine root component was not classified into live or dead fractions but visually approximately half, or about $8 \mathrm{t}$ /ha, were, living roots. Total living roots were estimated to be $27.5 \mathrm{t} / \mathrm{ha}$ from the cut blocks.

Table 1 Mean biomass and nutrient contents $(\mathrm{kg} / \mathrm{ha} \pm \mathrm{s}$.d.) of $100,200,400$ and $800 \mathrm{~kg}$ P/ha plots of herbage, litter, coarse and fine roots'of Caucasian clover excavated in November-December 1991.

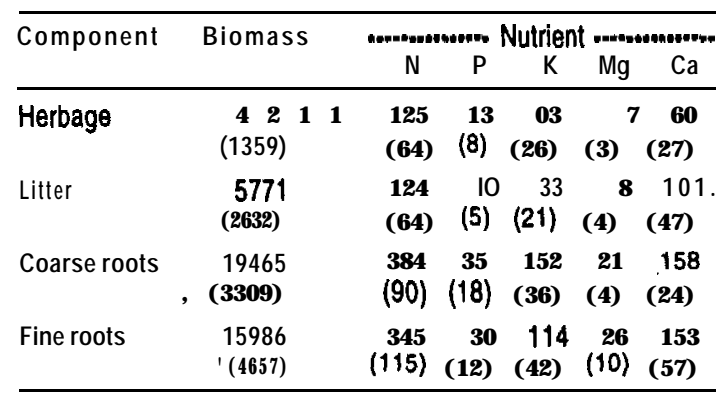

Root cores in O-10 cm, IO- $20 \mathrm{~cm}$ and $30-40 \mathrm{~cm}$ horizons contained $27.0+5.0,2.7+1.5,1.3+1.5$, and $0.6+0.6$ tha respectively, or 31.6 tha of total roots through the profile.
At the time of the second excavations on 23 February 1993 the soil was very dry and only living coarse roots were measured. These increased consistently with increasing rates of applied $\mathrm{P}$ to reach approximately 20 tha at the highest rate of fertiliser addition (Table 2). Coarse root biomass was therefore similar at the two times of excavation.

Table 2 Biomass and nutrient contents $(\mathrm{kg} / \mathrm{ha})$ of coarse roots and rhizomes of Caucasian clover excavated in late February 1993.

\begin{tabular}{|c|c|c|c|c|}
\hline \multirow[t]{2}{*}{ P applied } & \multirow[t]{2}{*}{, Biomass } & \multicolumn{3}{|c|}{............ Nutrient -.............. } \\
\hline & & $\mathbf{N}$ & 'p & $\mathbf{s}$ \\
\hline 6.25 & $\begin{array}{r}881 \\
(523)\end{array}$ & 15 & 1. 5 & 0.9 \\
\hline 50 & $\begin{array}{ccc}29 & 75 \\
(1400) & \end{array}$ & 58 & 2.7 & 2.3 \\
\hline 200 & $\begin{array}{l}15259 \\
(2240)\end{array}$ & 288 & 18.9 & 12. 2 \\
\hline 800 & $\begin{array}{l}20228 \\
(2729)\end{array}$ & 455 & 58.0 & 20. 6 \\
\hline Significan & $.01) \cdot{ }^{*}$ & $\because$ & $\cdot \square$ & ' \\
\hline
\end{tabular}

At both times of root excavation the phosphorus concentrations of coarse roots increased with increasing $\mathrm{P}$ fertiliser - from $0.15 \%$ to $0.29 \%$ in the $6.25800 \mathrm{~kg} \mathrm{P} / \mathrm{ha}$ gradient of the second excavation, and on both sampling occasions maximum values were similar. Sulphur concentrations were relatively low (0.08-0. 15\%).

Nutrient concentrations in coarse and fine roots were similar and averaged $2.07 \% \mathrm{~N}, 0.18 \% \mathrm{P}, \quad 0.73 \%$ $\mathrm{K}, \quad 0.13 \% \mathrm{Mg}$ and $0.86 \% \mathrm{Ca}$ in the Caucasian clover. dominant plots at the first excavation.

Nutrient contents in the combined root fractions were greater than in herbage (Table 1). Total nutrient content combining coarse and fine roots were (in $\mathrm{kg}$ / ha) $729 \mathrm{~N}, 65 \mathrm{P}, 266 \mathrm{~K}, 47 \mathrm{Mg}$ and $311 \mathrm{Ca}$, which were approximately 5 times higher than those of early summer herbage.

\section{Discussion}

Plants adapted to persist under cold winter environments need to have the ability to withstand frost-heaving, and the ability to survive many months without photosynthesis. The extensive and long-lived root system of Caucasian clover confers the species with these abilities. Because the rate of uptake of nutrients from cool soils is slow, it is likely that in the spring nutrients are mobilised from the large reserves in roots and rhizomes in order to match the 
increased demand resulting from the increase in rate of production of herbage at this time. In this way, the large nutrient content in roots and rhizomes may be functionally significant and so provide an explanation for the dominance of Caucasian clover in this environment over a 13-year period.

The major disadvantage in the maintenance of a large root system is the high cost of replacement following root death and of respiration. Since root respiration increases exponentially with increasing temperatures a cool environment should favour maintained high root:shoot ratios. Coarse roots appear to be relatively long-lived and the major component of root replacement appeared to be limited to the fine root component.

The consequences of long-term withdrawal of soluble soil nutrients into retained root nutrient pools needs to be examined further. Retention of calcium was about $470 \mathrm{~kg} / \mathrm{ha}$ through biomass and litter components in this study, in a soil which has approximately $1000 \mathrm{~kg} / \mathrm{ha}$ of calcium in the exchangeable form (Davis 1991). If release of calcium from litter to soil is limited to the rate of litter mineralisation (Gosz et al. 1973) then pH decline in soil could follow the introduction of calcium-retentive species like Caucasian clover. The relative dominance of the species might then be related to its ability to compete for nutrients in acidic soils (Bryant 1974). However, liming to balance induced calcium retention should be desirable to counter declining soil $\mathrm{pH}$. Nodulation was sparse in the present studies and may be a consequence of low $\mathrm{pH}$ (4.9) after 13 years of sward development.

This_phosphorus_gradient_trial_provided_visual evidence of a strong response to added P, about 200 $\mathrm{kg} \mathrm{P} / \mathrm{ha}$ being required over 13 years for near maximum herbage production.

The extensive network of roots and rhizomes combining to give root:shoot ratios of up to $4.6: 1$ with root and rhizome biomass up to 20 tha is a significant factor in the persistence of Caucasian clover in this harsh environment. Nutrient storage, as a function of underground biomass amounted to up to $58 \mathrm{~kg} \mathrm{P} / \mathrm{ha}$, $455 \mathrm{~kg} \mathrm{~N} / \mathrm{ha}$ and $20 \mathrm{~kg} / \mathrm{ha}$ of $\mathrm{S}$. This amount of phosphate equates to $650 \mathrm{~kg} / \mathrm{ha}$ of superphosphate. The ability to store and remobilise these nutrients over the growing season is a valuable attribute for this plant in the high country as in the absence of regular topdressing other legumes have failed to persist.

\section{REFERENCES}

Bryant, W.G. 1974. Caucasian clover (Trifolium ambiguum Bieb.)- A review. Journal of the Australian Institute of Agriculture Science 40: 1 1. 19.

Daly, G.T; Mason, C.R. 1987. Performance of Caucasian and Zigzag clovers. Proceedings of the NZ Grassland Association 48: 15 1 - 156.

Davis, M.R. 1991. The comparative phosphorus requirements of some temperate perennial legumes. Plant and soil 133: 17-30

Gosz, J.R.; Likens, G.E.; Bormann, F.H. 1973. Nutrient release from decomposing leaf and branch litter in the Hubbarb Brook Forest, New Hampshire. Ecological monographs 43: 173- 191.

Spencer, K.; Hely, F.W.; Govaars, A.G.; Zorin, M.; Hamilton, L.J. 1975. Adaptability of

Trifolium ambiguum Bieb. to a Victorian montane environment. Journal of the Australian Institute of Agriculture Science 41: 268-270.

Strachan, D.E. 1993. The importance of roots and rhizomes-as-storage-organs-of-nutrients-in-the persistence of Caucasian clover. BAgrSci honours dissertation, Lincoln University, New Zealand.

Yates, J.J. 1993. Growth and persistence of Trifolium ambiguum on 'high country' in Tasmania, Australia. Proceedings of the XVII International Grassland Congress: 1791-1792. 